Удк 616.411-089.873:612.13:[616-073:53.082.4

DOI 10.11603/2414-4533.2021.1.12024

ОМ. М. СТЕЦЬ, В. Р. АНТОНІВ, Т. М. ГАЛИГА

Національний медичний університет імені О. О. Богомольця

\title{
Оцінка стану кровопостачання тиреоїдного залишку за доплерівсыкими характеристиками після хірургічних втручань на щитоподібніӥ залозі
}

\begin{abstract}
Мета роботи: вивчити ехоструктуру, стан і особливості судинної перфузії тиреоїдного залишку щитоподібної залози після операції впродовж часу та визначення клінічної значущості кольорового доплерівського картування (КДК) та енергетичної доплерографії ЕД.

У 86 хворих після виконаних органозберігальних операцій на щитоподібній залозі провели дослідження тиреоїдного залишку на 7 день, через 1 місяць та 1 рік після операцій з використанням апарата ультразвукової діагностики Esaote MyLabX6 (Iталія) та HDI 5000 (ATL CША) з лінійним широкосмуговим датчиком L12-5 Мгц. Визначали величину та структурні зміни в залишеній тканині. Кровопостачання тканини та ї̈ оболонок вивчали шляхом визначень кількісних характеристик - індексу резистентності (RI), максимальної систолічної швидкості (МСШ), кінцевої діастолічної швидкості (КДШ) та енергетичної доплерографії (ЕД).

Збільшення об’єму частки чи кукси супроводжується зміною їх типу будови, з пласких (без форми) ділянок становляться шароподібними та конусоподібними, а темпи росту складають певний відсоток зміни типу будови у 37 (43 \%) хворих на 7 день і вже 66 (77 \%) - через 1 рік. КДК вказує, що кровопостачання тиреоїдного залишку проходить в основному по периферії у місцях новостворених сполученнях.

Впровадження ультразвукового доплерівського сканування для дослідження тиреоїдного залишку після операції дає можливість встановити ступінь кровообігу та швидкість компенсованого стану, що прослідковується за рахунок ультразвукових змін та залежить від типу будови залишеної тканини. Максимальний темп приросту тиреоїдної тканини та відновлення структури кровотоку спостерігається через 1 рік. Значення RI є найбільш інформативним кількісним показником периферичного кровообігу знову створених судинних з’єднань з тканинами.
\end{abstract}

Ключові слова: ультразвукова доплерографія; щитоподібна залоза; тиреоїдний залишок.

Постановка проблеми і аналіз останніх досліджень та публікацій. Серед різноманітних ендокринопатій захворювання щитоподібної залози займають провідну роль у патології людини, виходять на перше місце та набувають особливого значення як у плані діагностики, так і лікування під час та після операції [5, 6, 13].

Зростання числа хворих, яким виконували хірургічне лікування, спонукає до вирішення певних проблем у ранньому та пізньому післяопераційному періодах $[1,10]$. Складними завданнями $є$ диференціювання залишеної деформованої операцією тканини у часі та поява або залишення в тканині залози осередків у вигляді вузлів, вогнищ хронічного тиреоїдиту та активних чи пасивних зон кровообігу [2-4, 11].

Незважаючи на відомі діагностичні тести, ми вирішили вивчити стан залишеної тканини (тиреоїдного залишку) та іï̈ кровообіг із використанням кольорового доплерівського картування. Використання ефекта Доплера сприяє детальній характеристиці кровотоку цього органа. Об'єднання цих напрямків із доповненням кольорового доплерівського картування (КДК) розширює можливості діагностики за рахунок візуалізації кровотоку з врахуванням швидкості, напрямку й організованості потоку шляхом кодування інформації за допомогою кольору [7, 8]. Дуплексне сканування з КДК - сучасна інформативна діагностична технологія, яка здатна оцінити стан внутрішньоорганних судин шляхом детального аналізу параметрів кровотоку [9]. Впровадження в практику енергетичного доплерівського картування (ЕДК) вважають черговим розвитком КДК. Перевагою цього методу є висока чутливість до низької швидкості, що забезпечує візуалізацію повільного кровотоку при зміні її напрямку в місцях розгалуження малого току та незалежність до величини кута між доплерівським променем та напрямком кровотоку, та дає можливість диференціювати внутрішньотканинний кровообіг, оцінити архітектоніку новостворених судин $[8,9,12]$.

Мета роботи: вивчення ехоструктури, стану й особливостей судинної перфузії тиреоїдного залишку щитоподібної залози після операції у перебізі часу та визначення клінічної значимості КДК та ЕД.

Матеріали і методи. Обстеженню підлягало 86 хворих після виконаних органозберігаль- 
них операцій на щитоподібній залозі. На 7 день, через 1 місяць та 1 рік після операцій провели дослідження тиреоїдного залишку 3 використанням апарата ультразвукової діагностики Esaote MyLabX6 (Італія) та HDI 5000 (ATL CША) 3 лінійним широкосмуговим датчиком L12-5 Мгц. За допомогою апарата отримували зображення залишеної тканини, визначали ії величину, структурні зміни, кровопостачання тканини та її оболонок. Аналізували індекс резистентності (RI), максимальну систолічну швидкість (МСШ), кінцеву діастолічну швидкість (КДШ) та енергетичну доплерографію. RI більш точний показник, ніж швидкість кровотоку особливо щодо дрібних судин і визначається як відношення різниці між МСШ та КДШ до МСШ. Використання методу кольорового доплерівського картування дає характеристику кровообігу в декількох судинах дослідної ділянки, відображаючи напрямок і швидкість кровотоку в різні фази серцевого циклу з подальшим зіставленням кольорового зображення судин із чорно-білою картиною.

Результати досліджень та їх обговорення. Із визначення величини і ехоструктури тиреоїдного залишку у В-режимі почали розподіл останнього на плаский (без форми), трикутниковий, шароподібний, конусоподібний ультразвуковий тип будови тканини. Динамічне спостереження за станом тканини показує, що уже через 1 місяць змінюється тип будови кукси. У 12 (14 \%) плаский та трикутниковий тип ехобудови змінюється на шароподібний та конусоподібний, а через 1 рік продовжується зміна типу будови залишеної тканини (табл. 1).

Таблиця 1. Показники ультразвукової картини залишеної тканини щитоподібної залози

\begin{tabular}{|c|c|c|c|c|}
\hline \multirow{2}{*}{ № } & \multirow{2}{*}{$\begin{array}{c}\text { Тип будови } \\
\text { тканини }\end{array}$} & \multicolumn{3}{|c|}{ Період після операції } \\
\hline & & 7 день & 1 місяць & 1 рік \\
\hline 1 & Плаский (без форми) & 29 & 19 & 6 \\
\hline 2 & Трикутниковий & 20 & 18 & 14 \\
\hline 3 & Шароподібний & 22 & 29 & 34 \\
\hline 4 & Конусоподібний & 15 & 20 & 32 \\
\hline
\end{tabular}

Показники ультразвукової картини показують, що з перебігом часу змінюється форма тиреоїдного залишку та збільшується об'єм на кожній стороні за рахунок гіперплазії, проліферації епітелію чи лімфоїдній інфільтрації, фіброзу та неоплазії.

Збільшення об'єму частки чи кукси супроводжується зміною їхньої типу будови, з пласких (без форми) ділянок стають шароподібні та конусоподібні, а темпи росту складають певний відсоток зміни типу будови - 37 (43\%) хворих на 7 день і вже 66 (77\%) - через 1 рік.

У 86 хворих через 1 рік після операції у зв'язку 3 найбільш інформативними показниками провели дослідження з використанням якісних та кількісних можливостей КДК та енергетичного доплера. Встановлені наглядні параметри кровотоку тиреоїдного залишку.

При вузлових формах еутиреоїдного зоба у всіх вікових категоріях RI становитиме 0,68-0,61, при поєднанні вузлових форм зоб та автоімунного процесу - 0,65-0,74, у тиреоїдного залишку 3 вогнищевою автоімунною агресією на тлі гіпоти- реозу RI набуває значень 0,54-0,63. Великі коливання показників RI ми розцінювали як результат кровообігу по дрібній сітці судин, появу ділянок артеріовенозних шунтів та різноманітних звужень просвіту судин, рубцевих змін ззовні та прогресування основного захворювання всередині. Подальший аналіз показників таблиці вказує на чітке наростання з віком RI при кожній патології щитоподібної залози, тоді як МСШ та КДШ зберігають тенденцію до зниження результатів. Якісна оцінка кровопостачання залишеної тканини з урахуванням вікових груп зводилась до того, що хворі віком 60 років і старші, незважаючи на достатню в об'ємі залишену тканину під час операції мають здатність до послаблення кровообігу незалежно від типу захворювання. У 20 (23 \%) хворих існує поступова тенденція до прогресування цього стану з перебігом часу, що в кінцевому результаті проявляється стійкою клінікою гіпотиреозу.

КДК показало, що кровопостачання тиреоїдного залишку проходить в основному по перифе- 
Таблиця 2. Параметри кровотоку в залишеній тканині щитоподібної залози (через 1 рік після операції)

\begin{tabular}{|c|c|c|c|c|c|c|}
\hline $\begin{array}{c}\text { Вік } \\
\text { хворих }\end{array}$ & $\begin{array}{c}\text { Клінічний діагноз до } \\
\text { операції }\end{array}$ & $\begin{array}{c}\text { Кількість } \\
\text { спостережень }\end{array}$ & $\begin{array}{c}\text { Об’ємні } \\
\text { розміри, см }{ }^{3}\end{array}$ & RI & $\begin{array}{c}\text { МСШ, } \\
\text { см/с }\end{array}$ & $\begin{array}{c}\text { КДШ, } \\
\text { см/с }\end{array}$ \\
\hline $\begin{array}{c}20-44 \\
\text { роки }\end{array}$ & $\begin{array}{l}\text { Вузлові форми } \\
\text { еутиреоїдного зоба } \\
\text { Поєднання вузлових } \\
\text { форм зоба та } \\
\text { автоімунного процесу } \\
\text { Вогнищева автоімунна } \\
\text { агресія на тлі гіпотиреозу }\end{array}$ & $\begin{array}{l}14 \\
7\end{array}$ & $\begin{array}{l}4-8 \\
4-5\end{array}$ & $\begin{array}{c}0.68 \\
0.56 \pm 0.2 \\
0.45 \pm 0.1\end{array}$ & $\begin{array}{l}44.0 \pm 2.6 \\
46.0 \pm 2.4 \\
44.5 \pm 2.2\end{array}$ & $\begin{array}{l}6.2 \pm 1.1 \\
8.4 \pm 2.2 \\
6.8 \pm 1.6\end{array}$ \\
\hline $\begin{array}{l}45-59 \\
\text { років }\end{array}$ & $\begin{array}{l}\text { Вузлові форми } \\
\text { еутиреоїдного зоба } \\
\text { Поєднання вузлових } \\
\text { форм зоба та } \\
\text { автоімунного процесу } \\
\text { Вогнищева автоімунна } \\
\text { агресія на тлі гіпотиреозу }\end{array}$ & 13 & $\begin{array}{l}4 \\
2\end{array}$ & $\begin{array}{l}0.68 \pm 0.3 \\
0.58 \pm 0.2 \\
0.57 \pm 0.2\end{array}$ & $\begin{array}{l}42.0 \pm 1.8 \\
35.5 \pm 4.2 \\
39.2 \pm 4.0\end{array}$ & $\begin{array}{l}5.7 \pm 2.0 \\
6.7 \pm 3.2 \\
5.6 \pm 2.4\end{array}$ \\
\hline $\begin{array}{l}60 \text { p. i } \\
\text { старші }\end{array}$ & $\begin{array}{l}\text { Вузлові форми } \\
\text { еутиреоїдного зоба } \\
\text { Поєднання вузлових } \\
\text { форм зоба та } \\
\text { автоімунного процесу } \\
\text { Вогнищева автоімунна } \\
\text { агресія на фоні } \\
\text { гіпотиреозу }\end{array}$ & 2 & $\begin{array}{l}4-6 \\
2-4\end{array}$ & $\begin{array}{l}0.72 \pm 0.2 \\
0.62 \pm 0.1 \\
0.59 \pm 0.2\end{array}$ & $\begin{array}{l}36.0 \pm 1.2 \\
32.2 \pm 4.4 \\
38.8 \pm 2.6\end{array}$ & $5.4 \pm 2.0$ \\
\hline
\end{tabular}

рії в місцях сполучення. Лише у 9 (11\%) хворих молодого віку з активним кровотоком до операції при вузлових формах з’являлися сигнали кровотоку у власне паренхімі в кінці першого року спостереження. У 77 (89 \%) хворих оцінити судинну структуру залишеної тканини просторово як “судинну мапу” не можливо. Сюди слід віднести також безсудинні ділянки по краю тканини, тобто порушення кровообігу відбувається від периферії органа до його осередку. Цьому сприяють зміни кровопостачання під час операції при виконанні гемостазу з перев’язування судин, формування кукси, що мають статичний, склерозуючий ефект, сприяють явищам фіброзу, осифікації уже сформованих кукс чи ложа. Проте у 56 хворих із відновленим компенсованим станом через рік після операції з приводу вузлових форм еутиреоїдного зоба на тлі відносно однорідної структури 3’явилися множинні депікції, а у 3 хворих у режи- мі енергетичного доплера вдалося прослідкувати хід судин, що охоплюють залишену тканину (куксу) та пронизують гілками паренхіму.

Висновки. Впровадження ультразвукового доплерівського сканування для дослідження тиреоїдного залишку після операції дає можливість встановити ступінь кровообігу та швидкість компенсованого стану, що прослідковується за рахунок ультразвукових змін та залежить від типу будови залишеної тканини. Максимальний темп приросту тиреоїдної тканини та відновлення структури кровотоку спостерігається через 1 рік. Зміни типу будови ехоструктури тканини та судинна ехосеміотика не повинні слугувати тестом для встановлення діагнозу “рецидивний” зоб.

За допомогою використання КДК можна оцінити стан кровообігу тиреоїдного залишку, що змінюється залежно від віку та морфологічної 
структури, а значення RI є найбільш інформативним кількісним показником периферичного кровообігу знову створених судинних з'єднань із тканинами. Дослідженні особливості слід врахову- вати під час лікування хворих, яким призначали замісну терапію (L-тироксином). Використання КДК та ЕД робить діагностику післяопераційних змін тиреоїдного залишку якісно більш точною.

\section{СПИСОК ЛІТЕРАТУРИ}

1. Александров Ю. К. Пересмотр показаний для биопсии узлов щитовидной железы / Ю. К. Александров, Е. Д. Сергеева // Весник хирургии им. И. И. Грекова. - 2015. - № 1. - С. 23-25.

2. Делорм С. Руководство по ультразвуковой диагностике / С. Делорм. - Москва : Медпрес-информ., 2016. - 408 с.

3. Догра В. Секреты ультразвуковой диагностики / В. Догра, Д. Д. Рубенс. - Москва : Медпрес-информ., 2005. - С. 103 122.

4. Ультразвуковое исследование щитовидной железы / Джек-Бэскин-ст. Г., Дэниел С. Дюик, Роберт Э. Левин ; пер. с англ. под ред. В. Э Ванушко, А. М. Артемовой, П. В. Белоусова. - Москва : ГЭОТАР-Медиа, 2016. - 432 с.

5. Калинин А. П. Методы визуализации околощитовидных желез и паратиреоидная хирургия / А. П. Калинин, А. В. Павлов. Москва : Видар-М, 2010. - 231 с.

6. Карась А. С. Щитовидная железа и сердце / А. С. Карась, А. Г. Обрезан // Клиническая и експериментальная тиреоидология. - 2009. - Т. 5, № 9. - С. 37-42.

7. Куликов В. П. Основы ультразвукового исследования сосудов / В. П. Куликов. - Москва : Видар.-М, 2015. - 392 с.

\section{REFERENCES}

1. Aleksandrov, Yu.K., \& Sergeyeva Ye.D. (2015). Peresmotr pokazaniy dlya biopsii uzlov shchitovidnoy zhelezy [Revision of indications for biopsy of thyroid nodules]. Vesnik khirurgii im. I.I. Grekova - Grekov's Bulletin of Surgery, 1, 23-25 [in Russian]. 2. Delorm, S. (2016). Rukovodstvo po ultrazvukovoy diagnostike [Ultrasound Diagnostic Guide]. Moscow: Medpres-inform [in Russian].

3. Dohra, V., \& Rubens, D.D. (2005). Sekrety ultrazvukovoy diagnostiki [Secrets of ultrasound diagnostic]. Moscow: Medpresinform [in Russian].

4. Dzhek Beskin-st., Deniyels, S, Byuik, \& Robert, E. (2008). Ultrazvukovoye issledovaniye shchitovidnoy zhelezy [Thyroid ultrasound]. Vnushko, V.E., Artemova, A.M., Belousova, P.V. (Eds.). Moscow: GEOTAR-Media [in Russian].

5. Kalinin, A.P., \& Pavlov, A.V. (2010). Metody vizualizatsii okoloshchitovidnykh zhelez i paratireoidnaya khirurgiya [Methods for imaging the parathyroid glands and parathyroid surgery]. Moscow: Vidar [in Russian].

6. Karas, A.S., \& Obrezanm, A.G. (2009). Shchitovidnaya zheleza i serdtse [Thyroid gland and heart]. Klinicheskaya i eksperimentalnaya tireoidologiya - Clinical and Experimental Thyroidology, 5, 37-42 [in Russian].

7. Kulikov, V.P. (2015). Osnovy ultrazvukovogo issledovaniya sosudov [Fundamentals of vascular ultrasound examination]. Moscow: Vidar [in Russian].
8. Куликов В. П. Ультразвуковая диагностика сосудистых заболеваний. Руководство для врачей / В. П. Куликов, Н. Л. Доронина. - И. : Стром., 2007. - 512 с.

9. Лелюк В. Г. Ультразвуковая ангиология. Практическое пособие / В. Г. Лелюк, С. Э. Лелюк. - 3-е изд. - Москва : Реальное время, 2007. - 398 с.

10. Сенча А. Н. Ультразвуковое исследование. Поверхностно расположенные органы / А. Н. Сенча. Москва : Видар. M, 2015. - 512 c.

11. Сенча А. Н. Ультразвуковое исследование щитовидной железы. Шаг за шагом от простого к сложному / А. Н. Сенча. - Москва : Медпрес-информ., 2019. - 208 с.

12. Сенча Е. А. Применение количественного анализа ультразвукового исследования с контрасным усилением в дифференциальной диагностике очаговых изменений щитовидной железы / Е. А. Сенча, А. Н. Сенча, Э. И. Пеняева // Ультразвуковая и функциональная диагностика. - 2018. - № 2. - С. $12-26$

13. Труфанов Г. Е. Ульразвуковая диагностика опухолей мягких тканей / Г. Е. Труфанов. - СПб. : Элби., 2016. - 112 с.
8. Kulikov, V.P., \& Doronina, N.L. (2007). Ultrazvukovaya diagnostika sosudistykh zabolevaniy Rukovodstvo dlya vrachey [Ultrasound diagnostics of vascular diseases. A guide for doctors]. Moscow: Strom [in Russian].

9. Lelyuk, V.G., \& Lelyuk, S.E. (2007). Ultrazvtskovaya angiologiya. Prakticheskoye posobiye. 3-ye izdaniye [Ultrasound angiology. A practical guide 3rd edition]. Moscow: Realnoye vremya [in Russian].

10. Sencha, A.N. (2015). Ultrazvukovoye issledovaniye. Poverkhnostno raspolozhennyye organy [Ultrasound procedure. Superficial organs]. Moscow: Vidar [in Russian].

11. Sencha, A.N. (2019). Ultrazvukovoye issledovaniye shchitovidnoy zhelezy. Shag za shagom ot prostogo k slozhnomu [Ultrasound examination of the thyroid gland. Step by step from simple to complex]. Moscow: Medpres-inform [in Russian].

12. Sencha, Ye.A., Sencha, A.N., \& Penyayeva, E.I. (2018). Primeneniye kolichestvennogo analiza ultrazvukovogo issledovaniya $\mathrm{s}$ kontrasnym usileniyem $\mathrm{v}$ differentsialnoy diagnostike ochagovykh izmeneniy shchitovidnoy zhelezy [Using of quantitative analysis of ultrasound with contrast enhancement in the differential diagnosis of focal changes in the thyroid gland]. Ultrazvukovaya i funktsionalnaya diagnostika - Ultrasound and Functional Diagnostic, 2,12-26 [in Russian].

13. Trufanov, G.Ye. (2016). Ultrazvukovaya diagnostika opukholey myagkikh tkaney [Ultrasound diagnostics of soft tissue tumors]. Saint-Petersburg: Elbi [in Russian]. 
M. M. STETS, V. R. ANTONIV, T. M. GALYGA

O. Bohomolets National Medical University

\title{
ASSESSMENT OF THE STATE OF BLOOD SUPPLY OF THYROID RESIDUAL ACCORDING TO DOPPLER CHARACTERISTICS AFTER SURGERY ON THE THYROID GLAND
}

\begin{abstract}
The aim of the work: to study the echostructure, state and features of vascular perfusion of the thyroid residue of the thyroid gland after surgery over time and to determine the clinical significance of the CDC and ED.

Materials and Methods. The thyroid balance was examined in 86 patients, after the performed organ-preserving thyroid surgeries on the 7th day, 1 month and 1 year after the surgeries using ultrasound device the Esaote MyLabX6 (Italy) and HDI 5000 (ATL USA) with a linear broadband L12-5MHz sensor. The size and structural changes in the tissue left were determined. The blood supply to the tissue and its membranes was studied by determining quantitative characteristics - resistance index (RI), maximum systolic velocity (MSS), end diastolic velocity (EDS) and energy Doppler sonography (ED).

Results and Discussion. An increase in the volume of a lobe or stump is accompanied by a change in their type of structure, from flat (without a shape) areas they become sheet-like and conical, and the growth rate is a certain percentage of changes in the type of structure in 37 (43\%) patients on day 7 and already 66 (77\%) - after 1 year. The CDC indicates that the blood supply to the thyroid residue passes mainly along the periphery at the sites of newly created messages.
\end{abstract}

Key words: ultrasound dopplerography; thyroid gland; thyroid residue.

Н. М. СТЕЦЬ, В. Р. АНТОНИВ, Т. Н. ГАЛЫГА

Национальный медицинский университет имени А. А. Богомольца

\section{ОЦЕНКА СОСТОЯНИЯ КРОВОСНАБЖЕНИЯ ТИРЕОИДНЫХ ОСТАТКОВ ПО ДОППЛЕРОВСКИМ ХАРАКТЕРИСТИКАМ ПОС.ЛЕ ХИРУРГИЧЕСКИХ ВМЕШАТЕЛЬСТВ НА ЩИТОВИДНОЙ ЖЕЛЕЗЕ}

Цель работы: изучить эхоструктуру, состояние и особенности сосудистой перфузии тиреоидного остатка щитовидной железы после операции в течение времени и определение клинической значимости цветного допплеровского картирования (ЦДК) и энергетической допплерографии (ЭД).

У 86 больных после выполненных органосохраняющих операций на щитовидной железе провели исследования тиреоидного остатка на 7 день, через 1 месяц и 1 год после операций с использованием аппарата ультразвуковой диагностики Еsaote MyLabX6 (Италия) и HDI 5000 (ATL CШA) с линейным широкополосным датчиком L12-5 Мгц. Определяли величину и структурные изменения в оставленной ткани. Кровоснабжение ткани и ее оболочек изучали путем определения количественных характеристик - индекса резистентности (RI), максимальной систолической скорости (МСС), конечной диастолической скорости (КДС) и энергетической допплерографии.

Увеличение объема доли или культи сопровождается изменением их типа строения, из плоских (без формы) участков становятся пластообразными и конусообразными, а темпы роста составляют определенный процент изменения типа строения у 37 (43 \%) больных на 7 день и уже 66 (77 \% ) - через 1 год. ЦДК указывает, что кровоснабжение тиреоидного остатка проходит в основном по периферии в местах вновь созданных соединений.

Внедрение ультразвукового допплеровского сканирования для исследования тиреоидного остатка после операции позволяет установить степень кровообращения и скорость компенсированного состояния, которые прослеживаются за счет ультразвуковых изменений и зависят от типа строения оставленной ткани. Максимальный темп прироста тиреоидной ткани и восстановление структуры кровотока через 1 год. Значение RI является наиболее информативным количественным показателем периферического кровообращения вновь созданных сосудистых соединений с тканями.

Ключевые слова: ультразвуковая допплерография; щитовидная железа; тиреоидный остаток. 